\title{
STRATEGI KOMUNIKASI \\ SEKOLAH TINGGI THEOLOGIA JAFFRAY MAKASSAR \\ TERHADAP MASYARAKAT SEKITAR
}

\author{
Marthen Luter Tolong \\ sttjaffray@yahoo.com
}

\author{
PENDAHULUAN
}

\section{ABSTRAK}

MARTHEN LUTHER TOLONG. Strategi Komunikasi Sekolah Tinggi Theologia Jaffray Makassar Terhadap Masyarakat sekitarnya (Dibimbing oleh Muh. Nadjib dan Mursalim).

Tujuan penulisan ini adalah: (l) Untuk mengetahui sejauh mana STT Jaffray Makassar dengan masyarakat setempat; (2) Untuk mengetahui pengaruh positif atau negatif keberadaan STT Jaffray Makassar.

Penelitian ini dilaksanakan di Kampus Sekolah Tinggi Theologia Jaffray Makassar dan masyarakat sekitarnya di Jalan Gunung Merapi, Jl. S. Preman Lr. 55 Makassar. Adapun populasi penelitian ini adalah warga kampus STTJ dan warga sekitarnya. Responden penelitian ditentukan secara acak sederhana (Simple Random Sampling). Tipe penelitian ini adalah deskriptif kualitatif.

Data primer dikumpulkan dengan menggunakan kuesioner, obsevasi dan wawancara, sedangkan data sekundernya dikumpulkan melalui studi kepustakaan. Dari semua data yang sudah dikumpulkan selanjutnya dianalisis secara kualitatif deskriptif.

Hasil penelitian menujukan bahwa hubungan antara Sekolah Tinggi Theologia Jaffray Makassar dengan masyarakat sekitarnya adalah cukup harmonis, masyarakat sekitar merasa kehadiran kampus tersebut mempunyai dampak positif pada lingkungannya. Dari penelitian ini ditemukan juga bahwa masyarakat dapat menerima dengan baik kehadiran kampus tersebut karena warga kampus selalu ada kepedulian dan membangun kerja sama yang baik dengan semuap pihak seperti pemerintahan mulai dari RT, RW, Kelurahan dan seterusnya. Oleh warga setempt merasakan bahwa ada merasa memiliki dan berupaya untuk melindungi dari gangguan keamanan dari tindakan-tindakan orang-orang yang tidak bertanggung jawab.

\section{Latar Belakang Masalah}

Dalam kehidupan manusia sudah menjadi aksioma bahwa hubungan satu dengan yang lain itu adalah suatu hal yang mutlak dan tidak dapat ditolak, jika ada yang berpendapat lain atau mengatakan bahwa ia sanggup hidup tanpa orang lain maka orang yang demikian itu disebabkan karena dalam dirinya terjadi suatu kelainan kejiwaan.

Hidup rukun dan damai dengan semua orang adalah menjadi kerinduan bagi semua makluk manusia, hidup berdampingan satu dengan yang lain sekalipun ada perbedaan seperti budaya, suku, ras dan agama tetapi tidak dijadikan sebagai suatu persoalan yang dapat menimbulkan konflik di antara mereka. Pada dasarnya manusia yang sadar dan ingin menikmati hidup ini dengan baik pasti ada upaya untuk mempertahankan keadaan yang demikian yaitu ada kedamaian dan ketentraman dalam wilayah tempat beraktivitas atau secara keseluruhan alam semesta.

Oleh Bungin, ( 2007: 26 ) mengatakan bahwa "Manusia adalah mahluk sosial, maka manusia pada dasarnya tidak mampu hidup sendiri di dalam dunia ini baik sendiri dalam konteks fisik maupun konteks sosial budaya, terutama dalam konteks sosial budaya, manusia membutuhkan manusia lain untuk saling berkolaborasi dalam pemenuhan kebutuhan fungsifungsi sosial satu dengan lainnya. Karena pada dasarnya suatu fungsi yang dimiliki oleh manusia satu akan sangat berguna dan bermanfaat bagi manusia lainnya, karena fungsi- 
fungsi sosial yang diciptakan oleh manusia ditunjukkan untuk saling berkolaborasi dengan sesama fungsi sosial manusia lainnya dengan kata lain manusia sangat bermartabat apabila bermanfaat bagi manusia lainnya."

Juga oleh Rumanti ( 2004: 193 ) mengatakan bahwa :"Manusia adalah sentral dalam kegiatannya maupun dalam berkomunikasi. Jadi manusia tidak mungkin tanpa komunikasi. Semua tingkah laku macam apa saja merupakan kegiatan "komunikasi," sedang "diam" pun merupakan suatu komunikasi karena bagi orang lain berarti "aku tak bicara."

Dengan memahami apa yang diuraikan oleh Burhan Bungin dan Maria Assumpta Rumanti di atas, maka sangatlah memberi suatu penekanan bahwa hidup di alam ciptaan Tuhan ini tidaklah mungkin manusia akan memisahkan diri antara satu dengan yang lain, dan pasti akan membutuhkan orang lain sebagai bahagian dari kehidupannya.

Dalam kehidupan manusia ini baik dalam bentuk individu maupun yang bentuknya berkelompok, maka ada proses yang akan dilalui oleh setiap manusia yaitu proses berkomunikasi.

Melakukan komunikasi dengan orang lain itu sangat penting karena merupakan suatu keharusan bagi manusia. Manusia senatiasa berusaha membuka serta menjalin komunikasi atau hubungan dengan sesamanya karena melalui komunikasi itu akan menciptakan sesuatu yang dapat dimengerti bersama dan memberi makna bagi yang sedang menjalin proses komunikasi itu sehingga menghasilkan buah komunikasi yaitu ‘apakah terjadi hubungan yang renggang atau sebaliknya yaitu saling menerima dengan apa adanya dengan penuh harmonis. Sebaliknya peran komunikasi yang akan ditampilkan kepada orang lain mungkin dalam bentuk langsung atau tidak langsung, verbal atau nonverbal sehingga orang lain dapat memaknai dirinya seperti apa sesungguhnya, dan pasti keadaan ini akan memberi dampak pada orang lain tersebut, apakah umpan baliknya ( feedback) positif atau negatif dengan demikian fungsi komunikasi dalam hal ini tercapai.

Melalui proses komunikasi yang terjadi di antara individu dengan individu atau individu dengan kelompok bahkan kelompok dengan kelompok tidak jarang terjadi suatu konflik didalamnya, karena adanya perbedaan ketercapaian tujuan dari masing-masing individu atau kelompok.

Tujuan ideal dalam suatu kelompok masyarakat adalah terciptanya kepedulian dan saling hidup berdampingan dengan kondisi yang harmonis yaitu ada sikap peduli terhadap yang lainnya.

Sekolah Tinggi Theologia Jaffray Makassar adalah salah satu bahagian pendidikan khusus karena komunitas ini adalah sangat homogen keagamaan, mulai dari dosen, karyawan hingga mahasiswanya adalah beragama kristen. Juga melalui lembaga ini adalah pendidikan yang secara khusus untuk membentuk para mahasiswanya menjadi pelayan atau pemimpin dalam agama kristen yang mempelajari sesuatu yang tidak dapat dilihat oleh mata telanjang manusia tetapi hanya dapat dilihat oleh mata iman seseorang.

Dalam keberadaanya di tengah komunitas yang mayoritas, dengan melihat berbagai peristiwa yang terjadi di tanah air dimana terjadinya pengrusakan dan pembakaran atau penutupan salah satu tempat ibadah atau sekolah-sekolah tertentu, maka dapat dikatakan akan rawan terjadinya konflik sosial. Tetapi pada kenyataannya Sekolah Tinggi Theologia Jaffray Makassar sudah berdiri sejak tahun 1932 dan nampaknya mempunyai hubungan yang baik dengan semua kalangan terutama dengan masyarakat sekitar kampus tersebut. Tentu keadaan yang demikian ini hendaknya dipertahankan dan tetap dijaga sehingga menjadi suatu hal yang manarik bagi kelompok lain bahkan mungkin menjadi parameter ke depan.

Dengan berpatokan pada latar belakang tersebut di atas, penulis berusaha untuk mengkaji lebih jauh sehhingga dapat menjadi standar dalam pengembangan selanjutnya, dengan sebuah karya ilmiah yang berjudul : "Strategi Komunikasi Sekolah Tinggi Theologia Jaffray Makassar Terhadap Masyarakat Sekitarnya".

\section{Rumusan Masalah}

Dari gambaran permasalahan tersebut di atas mendorong penulis untuk menjawab pertanyaan pertanyaan yang timbul yaitu, 
1. Upaya apa yang dilakukan oleh Lembaga Sekolah Tinggi Theologia Jaffray Makassar terhadap masyarakat sekitarnya?

2. Apakah masyarakat merasakan ada kepedulian dari Civitas Akademika \& Tenaga kependidikan Sekolah Tinggi Theologia Jaffray Makassar ?

Tujuan Dan Kegunaan berikut:

Adapun tujuan dan kegunaan yang hendak dicapai melalui tulisan ini adalah sebagai

\section{Tujuan Penelitian:}

Berdasarkan rumusan masalah di atas maka tujuan penelitian adalah

1. Untuk mengetahui sejauh mana hubungan STTJ Makassar dengan masyarakat setempat.

2. Untuk mengetahui pengaruh positif atau negatif keberadaan STT Jaffray Makassar.

\section{Kegunaan Penelitian:}

1. Kegunaan Teoritis:

a. Dapat memberi informasi kepada lembaga Sekolah Tinggi Theologia Jaffray Makassar bahwa amat perlu dan penting untuk membangun hubungan yang harmonis dengan masyarakat setempat.

b. Sekurang-kurangnya dapat memahami dengan baik hal-hal yang menjadi kendala dalam berhubungan dengan masyarakat setermpat.

c. Sebagai bahan kajian untuk pengembangan lebih lanjut.

d. Sebagai bahan bacaan umum dan untuk penulis sendiri.

\section{Kegunaan Praktis:}

a. Masyarakat dapat memahami keberadaan bahwa Sekolah Tinggi Theologia Jaffray Makassar tidak terselubung tetapi ada rasa kebersamaan dengan orang lain tanpa memandang suku agama dan golongan.

b. Masyarakat dapat menerima keberadaan Sekolah Tinggi Theologia Jaffray Makassar sebagai mitra dalam membangun lingkungan dan masyarakat.

\section{Kerangka Konseptual}

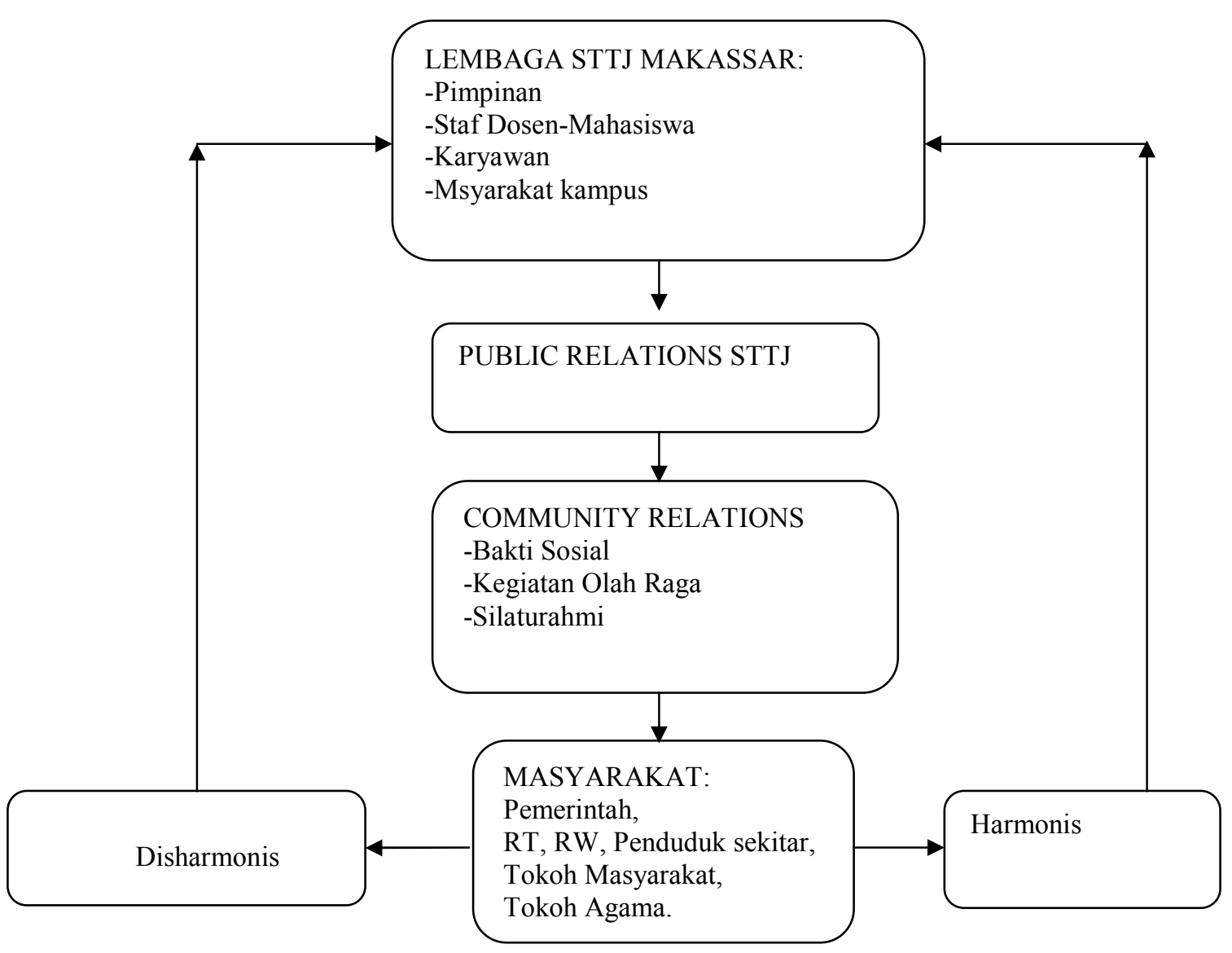

Gambar 1. Kerangka Konseptual 
Keharmonisan dalam masyarakat adalah hal yang menjadi kerinduan semua umat manusia, yaitu masyarakat saling menerima dengan keadaan dan kondisi apa adanya, sekalipun ada beberapa perbedaan yang menyolok tetapi tidak dijadikan sebagi suatu permasalahan.

Dalam upaya Sekolah Tinggi Theologia Jaffray Makassar untuk menjalin hubungan yang harmonis dengan masyarkat setempat, dapat terlihat pada gambar 1 di atas:

Pihak Sekolah Tinggi Theologia Jaffray Makassar melakukan proses komunikasi dengan masyarakat sekitar untuk mendapatkan suatu respon melalui beberapa unsur dalam lembaga tersebut misalnya pihak pimpinan STTJ dalam hal ini Puket III dan BEM yang berfungsi sebagai Public Relations. Proses komunikasi yang dilakukan sebagai berikut:

1. Membangun kerja sama melalui suatu kegiatan seperti kerja bakti bersama masyarakat sekitar.

2. Menyatakan kepedulian terhadap masyarakat sekitar khususnya dalam acara-acara keagamaan yaitu pihak Sekolah Tinggi Theologia Jaffray Makassar dapat berpartisipasi dengan memberi sumbangan untuk acara tersebut.

3. Sekolah Tinggi Theologia Jaffray Makassar sering meminjamkan ruangan dan fasilitas lainnya untuk kegiatan masyarakat.

4. Kerja sama dengan pihak pemerintah untuk membangun dan menciptakan ketentraman dan keamanan lingkungan.

5. Memberdayakan masyarakat sekitar untuk suatu kegiatan temporer.

6. Masyarakat kampus berupaya bersikap ramah terhadap masyarakat sekitarnya.

7. Melakukan Olah Raga bersama masyarakat setempat.

Dari upaya pendekatan yang dilakukan pihak Sekolah Tinggi Theologia Jaffray Makassar dapat memberi respon yang positif dari masyarakat sekitar dan terciptalah hubungan yang harmonis, mereka dapat menerima keberadaan sekolah tersebut. Oleh pihak Sekolah Tinggi Theologia Jaffray Makassar dalam membangun hubungan dengan masyarakat dan lingkungan sekitar tentu dengan tetap mempertimbangkan yang sebaik-baiknya sikap dan toleransi dalam hidup bermasyarakat terlebih keagamaan. Dipahami dengan sungguh bahwa menonjolkan budaya dan keagamaan dalam bermasyarakat hal itu akan memberi pengaruh yang negatif sehingga dapat menimbulkan suatu konflik.

Dalam menjalin hubungan yang baik ini tentu pihak Sekolah Tinggi Theologia Jaffray Makassar yang harus berperan aktif untuk menciptakan suatu suasana yang nyaman dan damai, pencitraan lembaga harus dijaga dengan memberi pembinaan kepada semua masyarakat kampus dalam berprilaku harus tampil dengan penuh kesopanan dan simpati pada masyarakat termasuk para tukang becak yang mencari nafkah di sekitar kampus STTJ Makassar.

\section{Definisi}

1. Strategi komunikasi adalah suatu konsep yang dapat diaktualkan kepada orang lain dan memberi feedback yang positif dan bermakna bagi yang berkomunikasi.

2. Civitas Akademik Sekolah Tinggi Theologia Jaffray adalah semua komponen yang ada dalam lembaga tersebut yaitu dosen, mahasiswa dan karyawan.

3. Harmonis adalah hasil dari suatu hubungan yang dapat memberi makna yang mendalam.

4. Masyarakat adalah manusia yang ada dalam suatu wilayah tertentu

\section{Metode Penelitian}

\section{Lokasi dan Waktu Penelitian.}

Penelitian dilakukan di Kampus Sekolah Tinggi Theologia Jaffray Makassar dan masyarakat di sekitarnya yaitu Jl. Gunung Merapi dan Jl. Sungai Preman. Waktu Penelitian: bulan Maret s/d April 2010

\section{Tipe Penelitian}

Tipe penelitian yang dipergunakan oleh penulis adalah penelitian deskriptif kualitatif, dimana dilakukan dengan kondisi yang alamiah, langsung ke sumber data dan peneliti sebagai instrument kunci. Penulis berhubungan langsung dengan pihak Sekolah Tinggi Theologia Jaffray Makassar dan masyarakat yang ada di sekitarnya.

\section{Teknik Pengumpulan Data:}




\section{Data Primer:}

1. Observasi: Suatu upaya yang dilakukan oleh penulis untuk melihat secara langsung objek penelitian yang ada hubungan dengan hasil penelitian.

2. Wawancara: Penulis mengadakan wawancara langsung di lokasi STT Jaffray Makassar dan masyarakat yang ada di sekitar nya yaitu Jl. G. merapi dan Jl. S. Pareman dan sekitarnya.

3. Kuisioner: Pengumpulan data dengan mengajukan daftar pertanyaan kepada responden yang ada kaitannya dengan permasalahan yang diteliti.

\section{Data Sekunder:}

Studi Pustaka: Penulis melengkapi data dengan sumber dari berbagai buku-buku atau literatur yang berkaitan dengan permasalahan yang diteliti.

\section{Populasi Dan Sampel}

Populasi: Populasi dalam penelitian ini adalah semua Civitas Academika Sekolah Tinggi

Theologia Jaffray Makassar dan masyarakat yang ada di sekitarnya.

Sampel: Penulis akan menggunakan penarikan sampel acak sederhana ( Simple Random Sampling ), yaitu penarikan sampel anggota populasi dilakukan secara acak tanpa memperhtikan strata dalam populasi.

\section{Teknik Analisa Data}

Dalam penelitian ini analisis data yang dilakukan adalah secara deskriftif kwalitatif dengan cara menguraikan data yang didapatkan di lapangan, baik itu data primer maupun data sekunder untuk memberikan yang jelas tentang permasalahan yang dibahas dalam penelitian ini.

\section{GAMBARAN UMUM LOKASI PENELITIAN}

\section{Sejarah Singkat Sekolah Tinggi Theologia Jaffray Makassar}

Pada tahun 1932 Sekolah Tinggi Theologia Jaffray Makassar didirikan oleh seorang misionaris Kristen yang berkebangsaan Skotlandia, dari negeri belahan utara benua Eropa yang bernama Robert Alexander Jaffray, ia dilahirkan pada tanggal 16 Desember 1873.

Dari latar belakang keluarga sesungguhnya berasal dari keluarga yang mampu untuk menyekolahkan anaknya karena memiliki sebuah perusahaan penerbitan yang mapan, tetapi pemuda RA Jaffray tidak tertarik untuk menjadi pengusaha dan milioner akan tetapi lebih tertarik pada pekerjaan yang melayani sesamanya manusia dalam bentuk membangun jiwa manusia untuk masa akhiratnya. Ia mengambil keputusan dan masuk dalam sebuah sekolah khusus yaitu Sekolah Misi di Kanada, setelah tamat, beliau memasuki organisasi Misionari yang bernama The Christian And Misionary Alliance ( CMA ) kemudian di utus menuju ke Asia untuk tugas penyebaran keyakinan Kristen mulai dari China selatan dan juga ke Vietnam.

Pada tahun 1928 ia diutus lagi masuk ke Indonesia dengan daerah tugasnya adalah Kalimantan, Irian Jaya, Bali dan Sulawesi. Pada tahun 1932 beliau mendirikan sebuah sekolah di kota Angin Mammiri Makassar, yang diberi nama "Sekolah Alkitab Makassar" ( SAM ) ia bertindak sebagai pimpinan dan pengajar di sekolah tersebut, namun karena gejolak perang dunia II maka ia ditangkap bersama dengan beberapa temannya yang berkulit putih dan dipenjarakan oleh tentara Jepang disuatu tempat yang tak layak dimana mereka ditempatkan di kandang kuda, akhirnya ia diserang penyakit disentri yang akhirnya pada tanggal 29 Juli 1945 ia meninggal dunia.

Kemudian dalam perkembangan selanjutnya pada tahun 1959 setelah Perang Dunia II meredah, nama sekolah tersebut berobah menjadi Jaffray Bible College ( JBC ) kemudian pada tahun 1975 JBS berganti nama lagi menjadi Sekolah Tinggi Theologia Jaffray Makassar (STTJ ) hingga sekarang. 
Kini Sekolah Tinggi Theologia Jaffray Makassar tetap berkembang sesuai arus saman,dari pemimpin ke kemimpin selalu menampakkan perkembangannya yang baik, dan selalu mengikuti aturan-aturan yang telah ditetapkan oleh pemerintah sehingga kini STTJ Makassar tetap mempertahankan statrus terakreditasi dari Badan Akreditasi Nasional ( BAN ) sebagai berikut:

1 Tahun 1975, STTJ Makassar berstatus TERDAFTAR di Kopertis Wilayah VII.

2 Tahun 1995 STTJ Makassar bertatus DIAKUI dengan SK Mendikbud No. 62/DIKTI/Kep/1995.

3 Tahun 1998 STTJ Makassar, berestatus TERAKREDITASI dari Badan Akreditasi Nasional ( BAN ) Perguruan Tinggi Depdikbud RI No. 002/BAN-PT/ Ak-II/1998 untuk Sl. Teologi dengan nilai $C$.

4 Tahun 2002 STTJ Makassar kembali mendapat status TERAKREDITASI dari Badan Akreditasi Nasional ( BAN ) Perguruan Tinggi Depdikbud RI No. 021/BAN-PT/ Ak-VI/ SI/ VIII/ 2002 dengan nilai B.

5 Tahun 2007, STTJ Makassar kembali mendapat Status TERAKREDITASI dari Badan Akreditasi Nasional ( BAN ) Perguruan Tinggi Depdikbud RI No. 2372/D/T/2007 dengan nilai B

6 Tahun 2005, STTJ Makassar khusus untuk program S2 juga terakreditasi dari Departemen Agama RI No. Dj.III/Kep/HK.00.5/ 251/2582/2005 dengan izin penyelenggaraan: Dirjen Bimas Kristen Depag RI No. Dj.III/Kep/HK.005/232/2562/2005.

7 Tahun 2010 STTJ Makassar telah mempersiapkan diri untuk mendapat kunjungan penilaian dari Badan Akreditasi Nasional.

Sekolah Tinggi Theologia Jaffray Makassar, kini membina program-program studi sebagai berikut:

1 Program Strata Satu Teologi ( S. 1) yang terbagi lagi dalam Konsentrasi:

a. Konsentrasi Teologi Kristen Protestan ( Th )

b. Konsentrasi Pendidikan Agama Kristen ( PAK)

c. Konsentrasi Musik Gerejawi ( MG )

d. Konsentrasi Pelayanan Anak Dan Remaja ( P. A. R. )

2 Program Strata Dua ( S. 2):

a. Program Studi Magister Teologi ( M. Th. )

b. Program Studi Magister Pendidikan Agama Kristen ( M. Pd. K.)

c. Program Studi Master Of Divinity ( M. Div. )

d. Program Studi Magister Konseling ( M. K. )

3 Program Strata Tiga ( S. 3): Program Doktoral Ministry (D. Min.).

Samapai saat ini Sekolah Tinggi Theologia Jaffray Makassar telah berhasil mencetak sarjana ( hamba-hamba Tuhan ) yang aktif melayani di ladang Tuhan dalam berbagai denomimasi gereja, yang tersebar di seluruh Indonesia bahkan di luar negeri. Selain itu juga ada yang melayani sebagai pegawai negeri sipil sesuai bidangnya.

Sekolah Tinggi Theologia Jaffray Makassar sedang mendidik mahasiswa sebanyak 437 orang yang terdiri dari program S1 dan S2 serta didukung oleh kurang lebih 30 dedominasi gereja. Jumlah staf dosen ( full time \& part time ) sampai saat ini berjumlah 27 orang, sedangkan karyawan berjumlah 14 orang. (daftar terlampir).

Dengan pencapaian ini, Sekolah Tinggi Theologia Jaffray Makassar terus dipacu untuk mengembangkan mutu pendidikan teologinya bagi perluasan kerjaan Allah dan pelayanan kepada masyarakat secara luas.

\section{Visi, Misi, Tujuan, Sasaran Dan Karakteristik STTJ Makassar}

1. Visi

Sekolah Tinggi Theologia Jaffray Makassar menjadi lembaga perguruan tinggi dan pusat pengembangan Theologia Kristen Protestan yang dengan kasih karunia Allah akan menghasilakn pemimpin dan pelayan yang dapat dipercaya, handal dan berkualitas, professional bagi gereja, masyarakat dan untuk nusa dan bangsa serta untuk diri sendiri.

2 Misi

Untuk mencapai visi tersebut, maka misi STTJ Makassar untuk periode ini adalah: 
a. Menyelenggarakan Tridarma Perguruan Tinggi secara inovatif dan berkualitas guna mendukung pembangunan masyarakat yang berkualitas dan pengembangan umat manusia yang bertanggung jawab kepada Tuhan.

b. Menyelenggarakan Pendidikan Alkitabiah bagi pengembangan dan pembangunan mental spiritual mahasiswa yang kelak akan menjadi pemimpin yang takut akan Tuhan, penuh hikmat, dan berkualitas serta memiliki kemampuan intelektual, iman dan dedikasi yang tinggi.

3. Tujuan:

a. Menghasilkan lulusan yang memiliki kemampuan pastoral yang handal, professional, dan berkualitas dalam berbagai aspek.

b. Menghasilkan pemimpin-pemimpin gereja yang mampu melayani bukan hanya di gereja tetapi juga di masyarakat luas guna membangun masyarakat yang berkualitas.

c. Menghasilkan pemimpin yang dapat bekerja sma dengan pemimpin gereja lainnya membangun umat Allah yang takut akan Tuhan dan penuh damai sejahtera.

d. Menghasilkan lulusan yang mampu beradaptasi dalam konteks Indonesia yang majemuk.

e. Memberikan layanan kepada gereja dan masyarakat dalam bidang pembinaan rohani Kristen.

f. Menghasilkan lulusan yang memiliki ketrampilan mengajar agama dan teologi Kristen yang baik di sekolah-sekolah umum atau di sekolah-sekolah teologi.

g. Menghasilkan lulusan yang memiliki ketrampilan music gerejawi baik dalam menciptakan lagu maupun dalam pesan pastoral.

4. Sasaran:

a. STT Jaffray Makassar mengoptimalkan program-program yang ada sehingga ada peningkatan jumlah mamasiswa yang masuk sebanyak 10\% setiap tahunnya dalam program studi, baik sajana maupun pascasarjana.

b. Meningkatkan kualitas teknik penjaringan mahasiswa baru setiap tahunnya sehingga calon mahasiswa yang datang sudah mengetahui tujuan dan panggilannya.

c. Mengadakan peningkatan kualitas pelayanan kepada mahasiswa lewat system penjaminan mutu akademik dan menjaga kualitas kehidupan spiritualitas ( spiritual formation) lewat pembinaan rohani harian di chapel dan asrama.

d. Menyediakan pelayanan kesejahteraan mahasiswa lewat beasiswa, kesehatan, dan kehidupan asrama yang baik.

e. Meningkatkan mutu lulusan dengan pemagangan di gereja-gereja dan di sekolahsekolah.

5. Karakteristik

a. Alkitabiah, yaitu Firman Allah sebagai otoritas yang tertinggi dan sebagai pedoman hidup STT Jaffray Makassar.

b. Akademik Pendidikan STT Jaffray Makassar diarahkan pada pencapaian standar akademik yang tinggi untuk menghasilkan lulusan yang bermutu akademik tinggi.

c. Akhlak STT Jaffray Makassar berusaha mempertahankan standar moral dan kesucian hidup.

d. Abdi di mana hamba-hamba Tuhan siap untuk melayani tanpa pamrih.

\section{Aktivitas Sekolah Tinggi Theologia Jaffray Makassar}

Berdasarkan Tri Darma Perguruan Tinggi, yaitu: Dharma Pendidikan dan Pengajaran, Dharma Penelitian dan Dharma Pengabdian pada Masyarakat, oleh Sekolah tinggi Theologia Jaffray Makassar juga tetap aktif menjalankan segala kegiatan yang ada kaitannya dengan Tri Dharma tersebut.

\section{Dharma Pendidikan Dan Pengajaran.}

Sesuai dengan visi, misi dan tujuan dari Sekolah Tinggi Theologia Jaffray Makassar, berupaya mengembangkan kurikulum yang standar dan baku untuk sebuah perguruan tinggi dan secara khusus sesuai tujuannya. Mahasiswa harus menerima proses pembelajaran dari dosen sesuai bidang keilmuannya. Dosen juga harus setiap saat mengembangkan diri dengan membaca literature baik melalui Perpustakaan dengan fasilitas buku sebanyak 15.143 judul dan 21.420 eksampelar maupun melalui fasilitas internet secara gratis serta lab Komputer. 
Juga para dosen mendapat kesempatan untuk pengembangan pengetahuan berdasarkan disiplin ilmunya dengan melanjutkan studi ke jenjang yang sesuai kebutuhan.

\section{Dharma Penelitian:}

Suatu perguruan tinggi yang ingin maju dan berkembang ke arah yang lebih tinggi dan berkualitas, harus mengembangkan kegiatan penelitian, STT Jaffray Makassar dalam pengembangannya telah mendorong dan mengaktifkan para dosen dan mahasiswa untuk melakukan penelitian sesuai bidang masing-masing dan diupayakan hasil penelitian itu dituangkan dalam suatu media seperti melalui Jurnal Jaffray. Melalui media ini para dosen dan mahasiswa dapat menyumbangkan hasil penelitiannya untuk menambah wawasan para pembacanya sekaligus sebagai informasi pengetahuannya.

\section{Dharma Pengabdian Pada Masyarakat.}

Salah satu program utama Sekolah Tinggi theologia Jaffray Makassar adalah pengabdian kepada masyarakat lebih kepada Tuhan, dosen, karyawan maupun mahasiswa tetap dituntut untuk mengabdi atau dengan bahasa iman kristiani adalah pelayanan. Dosen tidak hanya dituntut untuk mengajarkan mata kuliah yang menjadi binaannya tetapi juga harus bersiap untuk melayani secara khusus di gereja-gereja dengan tujuan membagikan suatu kebenaran yang dia ketahui. Jadi selain diberikan kepada mahasiswa di ruang kuliah juga di luar dan dapat diterima oleh masyarakat lainnya sehingga pengetahuan untuk masyarakat dapat bertambah dan iman orang kristen dapat disegarkan.

Demikian pulah para karyawan, tidak dituntut hanya mengabdi dalam lingkup tempat kerja di STT Jaffray Makassar saja tetapi juga dalam kehidupannya di tengah-tengah masyarakat secara luas dan umum, harus menampilkan suatu prilaku yang kristiani yang memiliki prilaku dan sifat keteladanan sehingga menjadi suatu teladan yang positif di masyarakat dimanapun ia berada atau bermasyarakat. Jadi pada dasarnya harus melekat pada diri pribadi prilaku yang sopan dan menghargai orang lain, mengasihi orang lain seperti dirinya sendiri.

Mahasiswa Sekolah Tinggi Theologia Jaffray Makassar, menjadi keharusan bahwa sejak mereka menjadi mahasiswa di STT Jaffray Makassar, sudah dibentuk menjadi manusiamanusia yang punya kepedulian dan pengabdian yang tinggi, baik itu untuk masyarakat sekitar dimanapun berada juga dalam lingkup keluarga sendiri pembentukan karakter yang demikian ini dimulai pada lingkungan kampus STT Jaffray Makassar.

Kemudian pada saat mahasiswa yang sudah menyelesaikan minimal 140 SKS diwajibkan untuk terjun ke masyarakat dalam hal ini di gereja-gereja untuk mengabdi ke masyarakat selama 6 bulan atau melaksanakan KKL dan PPL.

\section{Pengertian Mahasiswa STT Jaffray Makassar}

Yang dimaksud dengan mahasiswa STT Jaffray Makassar adalah

1. Mahasiswa yang terdaftar dan mendapatkan Nomor Pokok Mahasiswa (NPM). Mahasiswa baru dengan status bersyarat, belum dianggap sebagai mahasiswa samapai yang bersangkutan mendapat NPM.

2. Mahasiswa melakukan registrasi secara rutin pada setiap semester, termasuk mereka yang cuti dan yang dikena skorsing sekolah.

3. Mahasiswa yang tidak melakukan registrasi selama 2 semesterberturut-turut tanpa pemberitahuan melalui cuti akademik, maka secara otomatis status kemahasiswaannya gugur.

\section{Persyaratan Penerimaan Mahasiswa Baru STT Jaffray Makassar}

1. Persyaratan umum:

a. Telah memiliki pengalaman spiritual berjumapa dengan Tuhan Yesus sebagai Juruselamatnya. Karena pentingnya poin ini maka calon mahasiswa diwajibkan untuk menuliskan kesaksian tentang hal itu.

b. Terpanggil dan berbeban untuk melayani Tuhan

c. Berbadan sehat yang dibuktikan dengan surat keterangan dari dokter.

d. Surat keterangan berkelakuan baik dari Sekolah yang baru tammat dan dari kepolisian yang sudah tamat lebih dari 6 bulan.

e. Mempunyai rekomendasi untuk melanjutkan ke sekolah Teologi dari gereja atau lembaga yang relevan.

f. Memenuhi semua persyaratan yang ditetapkan oleh STT Jaffray Makassar.

g. Bersedia mentaati semua peraturan STT Jaffray Makassar. 
2. Persyaratan Akademik:

a. Beijazah SMU atau yang sederajat untuk program Sl.

b. Berijazah Sl. Teologi dan SI Umum untuk program Pascasarjana dengan IPK minimal 2,75 .

c. Lulus tes masuk dan wawancara.

d. Melewati tes atau program khusus Bahasa Inggris untuk program Pascasarjana.

e. Khusus untuk mahasiswa pindahan harus membawa surat keterangan pindah dari sekolah yang bersangkutan disertai transkrip mata kuliah yang telah dilulusi.

3. Persyaratan Administrasi:

a. Foto copy Ijazah dan NEM yang telah dilegalisir sebanyak 6 lembar.

b. Foto copy Akte Kelahiran atau Kenal Lahir.

c. Foto kopy Surat Baptisan atau Surat Sidi.

d. Surat Rekomendasi dari Gereja

e. Surat Kelakuan baik dari Sekolah yang baru tamat, dan dari kepolisian yang sudah melewati enam bulan tamat.

f. Surat pernyataan dari Sponsor.

g. Pas foto terbaru ukuran:

$-3 \times 4 \mathrm{~cm}$ sebanyak 8 lembar

$-2 \times 3 \mathrm{~cm}$ sebanyak 6 lembar.

\author{
Alamat Lengkap Sekolah Tinggi Theologia Jaffray Makassar: \\ SEKOLAH TINGGI THEOLOGIA JAFFRAY MAKASSAR \\ Jl. Gunung Merapi No. 103;Kelurahan Lajangiru \\ Kecamatan Ujung Pandang \\ Kota Makassar \\ Kotak Pos: 1054 \\ Kode Pos: 90010 Sulawesi Selatan Indonesia \\ Telepon ( 0411) 324129, 325961, Fax 311766, E-Mail: sttjmks@yohoo.co.id
}

\title{
Struktur Organisasi Sekolah Tinggi Theologia Jaffray Makassar \\ Sistem Organisasi
}

Perlu di pahami bahwa dalam suatu organisasi amat sangat penting peranannya sebuah struktur organisasi karena lewat struktur ini segala operasional dapat dijalankan dengan baik dan dapat mencapai tujuannya.

Penyelenggaraan Sekolah Tinggi theologia Jaffray Makassar terkait pada system integrasi sebagaimana yang tercantum dalam statute STT Jaffray Makassar yang meliputi struktur organisasi, mekanisme kerja, mekanisme koordinasi antara bidang dan program studi, mekanisme pengambilan keputusan, dan mekanisme pemantauan.

Struktur Organisasi dan Tugas.

STT Jaffray Makassar pada hakikatnya telah mengikuti system organisasi Sekolah Tinggi sesuai dengan peraturan pemerintah yang dituangkan dalam PP No. 30 tahun 1990 tentang pendidikan tinggi yang telah diperbaharui dengan PP No. 66 tahun 1999.

Mekanisme Kerja.

Gereja Kemah Injil Indoneia ( GKII ) sebagai pendiri dan pemilik STT Jaffray Makassar melalui Yayasan Jaffray Makassar sebagai badan penyelenggara merupakan penentu kebijakan umum penyelenggaraan STT Jaffray Makassar. Badan Penyelenggara merumuskan dan menetapkan garis-garis besar dan pedoman pengelolaan STT Jaffray Makassar, sedangkan pimpinan merupakan pelaksana operasional dalam penyelenggaraan program pendidikan yang dibantu oleh pembantu-pembantu ketua di bidang masing-masing. Senat STT Jaffray Makassar adalah badan normatif dan perwakilan tertinggi yang merumuskan dan menetapkan norma-norma dan kriteria-kriteria serta penelitian kinerja penyelenggaraan STT Jaffray Makassar. Dalam jalur tanggung jawab pembantu-pembantu ketua bertanggung jawab kepada ketua, ketua bertanggung jawab kepada pimpinan Yayasan Pendidikan Jaffray Makassar dan Badan Pengurus Pusat GKII. 
Mekanisme Koordinasi.

Koordinasi penyelenggaraan kegiatan program studi diatur melalui ketua-ketua jurusan/program studi dan koordinasi konsentrasi yang disentralisasi pada biro akademik.

Mekanisme Pengambilan Keputusan:

Pertama; Ketua STT Jaffray Makassar dalam mengambil keputusan memberi intruksi, pedoman dan penetapan secara umum. Kedua; Pada prinsipnya pengambilan keputusan pada setiap jenjang wewenang dan tanggung jawab dilaksanakan secara demokratis yang terbuka pada rapat-rapat yang resmi.

Mekanisme Pemantauan:

Pertama; Pemantauan dalam pelaksanaan kegiatan akademik dilakukan oleh Pembantu Ketua I ( Puket I ) Bidang Akademik. Disamping itu tugas pengawasan meliputi penelitian dan Perpustakaan. Kedua; Pemantauan dalam pelaksanaan kegiatan administrasi Dan Keuangan oleh Pembantu Ketua II ( Puket II ) Bidang Adminstrasi Dan Keuangan. Ketiga; Pemantauan dalam pelaksanaan kegiatan kemahasiswaan dilakukan oleh Pembantu Ketua III ( Puket III ) Bidang Kemahasiswaan. Keempat; Tugas ini semua dilaporkan secara kerkala kepada Ketua STT Jaffray Makassar.

Bagan Struktur STT Jaffray Makassar ( lihat pada lampiran II tentang Struktur Organisasi STTJ Makassar).

Sekolah Tinggi Theologia Jaffray Makassar mempunyai struktur kerja sebagai berikut:

1. Yayasan Pendidikan Jaffray Makassar, dengan tugas utamanya adalah mengupayakan pengembangan STTJ Makassar baik pisik maupun non pisik. Dengan struktur kepengurusannya sbb:

Ketua dan Wakil Ketua

Sekretaris dan Wakil Sekretaris

Bendahara dan Wakil Bendahara

Anggota-anggata/ Seksi.

2. Unsur Pimpinan Inti yaitu:

Ketua Sekolah

Pembantu Ketua I ( Puket I)

Pembantu Ketua II ( Puket II )

Pembantu Ketua III ( Puket)

Ketua Sekolah Tinggi Theologia Jaffray Makassar, yang dijabat oleh Pdt. Dr. Daniel Ronda,Th. M.

Ketua STTJ yang bertanggung jawab sepenuhnya untuk segala aktivitas kedalam dan keluar.

Pembantu Ketua I (Puket I), yang dijabat oleh

Pdt. Dr. Ivan Th. J. Weismann, S. Th., M. Hum.

Puket I, bertanggung jawab untuk Bidang Akademik

Pembantu Ketua II (Puket II) yang dijabat oleh

Pdt. Dr. (Cand) Jermia Djadi, M. Th.

Puket II, bertanggung jawab untuk Bidang Keuangan dan pengaturan tata kerja.

Pembantu Ketua III (Puket III), yang dijabat oleh

Pdt. Dr. (Cand) Peniel Cornelius D. Maiaweng, M. Th.

Puket III, bertanggung jawab untuk Bidang Kemahasiswaan.

\section{Sistem Informasi.}

Sistem informasi dalam lingkungan STT Jaffray Makassar dapat dikendalikan secara baik karena lingkungan terbatas dan system relevan. Disamping jalur informasi yang biasa seperti; brosur, papan pengumuman, bulletin, telepon dan lainnya, jalur informasi yang sangat efektif dalam lingkungan STT Jaffray Makassar adalah melalui acara ibadah yang diselenggarakan setiap hari pada pagi hari dari hari Senin samapai Jumat yang merupakan kewajiban bagi semua dosen, karyawan dan mahasiswa.

Penampungan dan penyaluran informasi serta kebijakan Pimpinan STT Jaffray Makassar dapat dilakukan melalui rapat rutin staf pimpinan pada hari Rabu setiap minggu yaitu Ketua sendiri, Puket I, Puket II, Puket III dan unsur lain sesuai kebutuhan misalnya ketua-ketua konsentrasi. 
Proses desiminasi informasi yang dilakukan ditingkat STT Jaffray Makassar dan program studi dengan pelaksanaan sebagai berikut:

1 Kebijakan yang perlu disosialisasikan pada tingkat STT Jaffray Makassar, maka diseminasi dilakukan di tingkat STT Jaffray Makassar.

2 Kebijakan yang perlu disosialisasikan pada tingkat program studi, maka desiminasi informasi dilakukan di tingkat program studi.

Diseminasi informasi tidak hanya berupa penyerahan kebijakan sekolah, tetapi juga dilakukan diseminasi hasil penelitian, laporan pelayanan Kuliah Kerja Lapangan, Laporan Kegiatan Lembaga. Hal ini dilakukan dalam bentuk acara khusus di Chapel STT Jaffray Makassar yang dihadiri oleh segenap civitas akademika STT Jaffray Makassar. Akhirnya informasi kepada mahasiswa meliputi info tentang lowongan kerja pelayanan, kesempatan untuk mendapat beasiswa, lowongan untuk Praktek Kerja Lapangan ( PKL) yang biasa dibutuhkan dan disediakan oleh gereja-gereja atau lembaga lainnya bahkan dari pemerintah.

\section{Manajemen Sumber Daya Manusia}

Suatu perusahaan, organisasi atau lembaga tidak dapat melakukan suatu aktivitas tanpa didukung oleh sumber daya yang memadai, Sekolah Tinggi Theologia Jaffray Makassar dalam operasionalnya sangat didukung oleh sumber daya manusia yang memadai sebagai berikut:

Dosen

Proses belajar mengajar pada Sekolah Tinggi Theologai Jaffray Makassar, sangat ditunjang oleh tenaga-tenaga pengajar ( dosen ) yang memdai yang direkrut sesuai dengan kebutuhan dan kualifikasi keahlian dalam mengajar, sehingga visi, misi dan tujuan dapat tercapai dan ada kesesuaian dengan garis-garis besarprogram STT Jaffray Makassar.

Dalam proses perekrutan tenaga pengajar ( dosen ) telah ditentukan persyarakatan yang utama sebagai berikut:

1 Harus lulusan sesuai dengan bidang studi yang dibutuhkan.

2 Pendidikan atau Ijazah minimal Sl, dengan IPK Ijazah minimal 3,00.

3 Komitmen moral dan keyakinan serta spiritualnya.

4 Persyaratan lain yang sudah ditetapkan oleh Yayasan Pendidikan Jaffray Makassar dan STT Jaffray Makassar.

\section{Karyawan}

Tenaga karyawan merupakan bahagian yang tak terpisahkan dari seluruh kegiatan proses belajar mengajar di STT Jaffray Makassar. Oleh karena itu dalam merekrut dan mempekerjakan tenaga karyawan STT Jaffray Makassar memanfaatkan tenaga seefesien mungkin dengan memilih dan menempatkan karyawan sesuai dengan bidang dan keperluan yang ada.

Segala sesuatu yang berkenaan dengan ketenagakerjaan karyawan ditetapkan dalam peraturan Yayasan Pendidikan Jaffray Makassar yang tentunya tidak bertentangan dengan peraturan ketenagakerjaan Depnaker RI. Di bawah bimbingan Pembantu Ketua II Bidang Administrasi Dan Keuangan setiap karyawan dibina sedemikian rupa termasuk pembinaan mental spiritual dengan berusaha memperhatikan dan meningkatkan profesionalisme dan kesejahteraan mereka.

Karyawan dan dosen STT Jaffray Makassar, dibekali dengan suatu pemahaman yang mendalam bahwa pengabdian atau bekerja adalah suatu tugas dan pelayanan yang dipercayakan Tuhan kepada setiap orang. Jadi ketika bekerja di STT Jaffray Makassar adalah merupakan suatu panggilan dan pelayanan kepada Tuhan dan terhadap sesama yang tentunya dipastikan akan mendapat ganjaran dari Dia yang pemilik hidup dan kehidupan ini, baik di dunia ini maupun di akhirat nantinya. 


\section{HASIL PENELITIAN DAN PEMBAHASAN}

\section{Hasil Penelitian}

Pada Bab IV ini merupakan data dari hasil penelitian yang diperoleh dari hasil wawancara dengan beberapa sumber sebagai informan yang oleh penulis meyakini bahwa mereka dapat dipercaya untuk memberi informasi yang sesungguhnya dan mereka reliabel sebagai informan. Penulis telah melakukan penelitian selama dua bulan untuk mendapatkan data yang dapat mengungkapkan tentang suatu strategi komuniksi yang dapat dilakukan oleh Sekolah Tinggi Theologia Jaffray Makassar sehingga dapat mengembangkan diri dan dapat diterima oleh berbagai kalangan terlebih khusus untuk masyarakat sekitarnya.

Wawancara dilakukan kepada beberapa informan yaitu Ketua STT Jaffray Makassar, Puket I, Puket II, Puket III, 3 dosen biasa dan Ketua-ketua Konsentrasi. Kemudian penulis juga melakukan wawancara dengan beberapa mahasiswa STT Jaffray Makassar, kemudian mengadakan wawancara dengan beberapa masyarakat yang bertempat tinggal sekitar kampus STT Jaffray Makassar dan tokoh tokoh agama.

Perlu juga dijelaskan bahwa STT Jaffray Makassar dalam menjalankan strategi komunikasinya ada dua kelompok masyarakat yang menjadi sasarannya yaitu:

1. Masyarakat yang tinggal di sekitar Kampus Sekolah Tinggi Theologia Jaffray Makassar. Salah satu ayat yang terdapat dalam kitab suci agama Kristen mengatakan bahwa "Janganlah engkau datang di rumah saudaramu pada waktu engkau malang. Lebih baik tetangga yang dekat dari pada saudara yang jauh" ( Amsal 27: 10b ) Dari ayat tersebut di atas memberikan suatu penggambaran bahwa hidup bertetangga itu adalah sangat penting dan dapat menentukan bagaimana hubungan satu dengan yang lain.

2. Anggota gereja-gereja yang tersebar di seluruh penjuru tanah air di Indonesia bahkan di luar negeripun. Kepada gereja-gereja yang tersebar di tanah air, kepadanya diinformasikan tentang kelebihan dan keunikan program-program dari sekolah tersebut sehingga memungkinkan ada dari anggota gereja tersebut tertarik dan dapat mengutus anaknya atau keluarganya untuk menggabung belajar di Sekolah Tinggi Theologia Jaffray Makassar. Bahkan tidak menutup kemungkinan untuk membantu dalam kebutuhankebuthan yang berkaitan dengan pengelolaan sekolah tersebut.

Dari pihak Sekolah Tinggi Theologia Jaffray Makassar dalam menjalankan fungsi Public Relations telah menempuh langkah-langkah sebagai berikut:

1 Menciptakan hubungan yang baik dengan tetangga terdekatnya dengan berbagai cara yang dapat diterima oleh masyarakat setempat, misalnya melakukan bakti sosial, dan memperdulikan hal-hal yang menjadi kebutuhan masyarakat sekitar misalnya dengan membagi-bagi sembako.

2 Dalam kegiatan keagamaan misalnya saat umat muslim beribadah puasa, maka masyarakat kampus harus mengharagai dengan tidak beraktivitas saat jam sembahyang, kemudian melakukan kegiatan buka puasa bersama yang dapat dihadiri oleh pemerintah setempat.

3 Dapat memberi bantuan daging kurban pada saat hari raya Idhul Adha kepada masyarakat sekitar.

4 Memberi kesempatan untuk menggunakan halaman kampus dalam suatu kegiatan, misalnya saat pemilihan Umum.

Berikut ini Penulis akan memaparkan hasil wawancara yang didapatkan di lapangan terhadap beberapa informan ( Daftar Informan lihat Lampiran 2 ) sebagai berikut:

Dari Masyarakat:

Ny. Chatrina Pandung ( 52 ) mengungkapkan pengalamannya bertetangga dengan kampus bahwa:

"Sekolah Tinggi Theologia Jaffray Makassar pada dasarnya telah memberikan perhatian kepada kami yang tinggal dekat dengan kampus tersebut, karena setiap saat mereka datang membersihkan lingkungan kami sehingga kebersihan tetap terjaga. Demikian juga karena ada beberapa mahasiswa yang keluar masuk di kampusnya maka otomatis mereka singga di kios-kios kami untuk membeli barang dagangan kami."

Lain lagi dengan beberapa warga keturunan Tionghoa, pemilik toko dan Toko Listrik, yang berdomisili di sekitar Jl. G. Merapi mengatakan bahwa: 
"Keberadaan Sekolah Tinggi Theologia jaffray Makassar sangat mendukung kelancaran usaha kami karena mereka selalu berkunjung ke toko kami untuk membeli keperluannya sehingga barang-barang dagangan kami sangat lancar, sekalipun ada juga yang biasa melakukan kekeliruan seperti meminjam dan lambat membayarnya dan ada yang lupa sama sekali. Selain itu mahasiswanya tidak ada yang berdemo-demo seperti dengan kampus lain, mungkin karena mereka semua calon pendeta".

Arham ( 45 ), Mukdin Syarif ( 57 ) Ketua dan Wakil ORT C Rw III Kel. Lajangiru beralamat di Jl. S. Preman Lr.55 No.13, menuturkan bahwa:

"Kehadiran kampus Sekolah Tinggi Theologia jaffray Makassar memberikan manfaat baik secara ekonomi juga secara moral, manfaat ekonomi adalah warga yang punya rumah kontrakan atau memiliki kios atau toko-toko kecil disekitar kampus pasti yang banyak memanfaatkannya adalah warga kampus utamanya bagi mahasiswanya. Kemudian dari segi moral, pada dasarnya masyarakat merasakan perbedaan pergaulan seorang mahasiswa teologi dengan mahasiswa lainnya sangat berbeda mungkin karena mereka dididik tentang moral dan hubungan antara Allah dan manusia sehingga perilaku mereka, kami menilainya sebagai mahasiswa yang sopan dan ramah."

Ibu Sulawati Sukur, SE ( 60 ), Ketua ORW III Kel. Lajangiru, mengungkapkan bahwa: "warga kampus STT Jaffray Makassar selalu menampakkan rasa kebersamaannya dengan warga setempat dan dapat menjalin kerja sama yang baik dengan pemerintah khususnya malai dari tingkat RT, RW, Kelurahan, samapi di kecamatan. Misalnya saat bila ada mahasiswa yang masuk di asrama STTJ mereka sudah siapkan surat keterangan pindah penduduk dari daerah asal sehingga tidak menyulitkan petugas untuk pengambilan KTP. Dari kampus itu juga selalu kerja sama dengan kami untuk bakti sosial sehingga lingkungan tetap bersih."

Daeng Talli (61 ) beralamat di Jl. S. Preman Lr. 55 mengungkapkan pengalamannya bertetangga dengan kampus Sekolah Tinggi theologia Jaffray Makassar sebagai berikut:

Pertama; Bertetangga dengan sebuah kampus kita harus mampu menerima segala resiko, karena namanya kampus pasti didalamnya ada manusia-manusia berhimpun dari berbagai latar belakang budaya, ada yang sopan, ada yang kasar dan lain-lain sehingga dalam berinteraksi dengan masyarakat sekitarnya akan member dampak, misalnya ada yang kebiasaannya lancang-lancang untuk berkunjung ke rumah warga yang dekat dengan kampus yang sering bertamu terlalu jauh malam sehingga yang punya rumah merasa terganggu. Kedua; Kampus pada umumnya penuh dengan suatu kegiatan yang melibatkan banyak orang misalnya, ketika kampus itu melaksanakan kegiatan olah raga, maka otomatis warga disekitar kampus itu akan terganggu karena adanya suara yang riuh rendah atau bersorak-sorak. Ketiga; Sekalipun demikian kami selaku masyarakat yang berdekatan dengan mereka merasakan manfaat keberadaannya, mereka dapat membersihkan lingkungan kami dan juga ada kepedulian misalnya saat umat islam melaksanakan ibadah puasa, sering dari kampus menawarkan untuk membantu warga untuk melaksanakan buka puasa bersama dengan cara mereka menyediakan dana untuk keperluan acara tersebut.

Daeng Amir, Daeng Dulla dan sejumlah rekan seprofesinya sebagai abang becak yang beroperasi di sekitar Jl. G. Merapi mengungkapkan pengalamannya bergaul dengan warga kampus sebagai berikut:

Pertama; Warga kampus STTJ sangat membantu kami dalam mencari nafkah setiap hari, karena kampus tersebut dihuni kurang lebih 250 orang yang tinggal di dalam kampus ( asrama putra dan asrama putri, juga ada asrama dosen ) ditambah dengan mahasiswa yang tinggal di luar kampus sehingga kami selaku abang becak dapat mengantarnya sesuai kebutuhannya. Kedua; Ketika kami mengantar atau menjemput mereka pada umumnya tidak terjadi tawar menawar untuk jasa kami selalu ada pengertian dari mereka, sekalipun ada juga yang tidak dapat membayar pada saat itu tetapi dia membayar pada kesempatan lain ketika ia sudah memiliki uang. Ketiga; Kami sangat menganggap mereka itu sebagai keluarga sendiri, bahkan sering bila ada keluarga mahasiswa datang dari daerah kami inapkan di rumah kami. Keempat; Kami bertekad untuk menjadi sahabat dan melindungi kampus STTJ Makassar dari gangguan apapun sebatas yang dapat kami lakukan.

Rusli Sumang ( 39 ) mengatakan bahwa: 
"Seajak saya tinggal di sekitar kampus STTJ tahun 1987 hingga sekarang, tidak perna terjadi persoalan antara masyarakat dengan pihak STTJ, jadi ini membuktikan bahwa terjadi hubungan yang harmonis, ini disebabkan karena pihak STTJ selalu berpartisipasi dengan kegiatan-kegiatan kemasyarakatan. Untuk lebih baik lagi pihak STTJ harus menjaga dan meningkatkan hubungan dengan masyarakat setempat."

Seorang Tokoh Agama Islam, Ustahas Baharuddin,S.Ag ( 45 ) yang bertugas di Masjid Al Baithul Makmur, Jl. S Preman Lr. 54, memberi penjelasan kepada penulis bahwa:

"Terjadinya konflik di suatu tempat karena kurangnya saling pengertian dan karena tidak ada kepedulian kepada orang lain khususnya pendekatan kepada komunitas yang punya pengaruh di suatu tempat. Juga konflik terjadi karena dering kelompok tertentu memaksakan kehendaknya, misalnya di tempat tersebut mayoritas warga tidak setuju membangun suatu tempat ibadah atau sekolah atas nama agama, tetapi oleh yang berkepentingan berkeras dan menempu cara-cara yang illegal untuk meloloskan kehendaknya, maka otomatis hal itu akan memicu konflik. Tetapi untuk STT Jaffray Makassar sampai saat ini warga tetap mendukung keberadaannya karena mereka tidak berbuat yang bertentangan dengan norma-norma di masyarakat."

Seorang staf Kelurahan Lajangiru memberi komentar pada penulis tentang STT Jaffray Makassar bahwa:

"untuk warga kampus STT Jaffray Makassar selalu menampakkan kerja sama yang baik selama ini, mereka tidak menolak kalau dari pihak kelurahan membutuhkan ruangan atau lokasi untuk suatu kegiatan tertentu seperti pada saat pemilu maka kampleks STTJ menjadi trempat kegiatan kami, dan banyak hal yang dinikmati oleh warga yang lain."

\section{Dari Sekolah Tinggi Theologia Jaffray Makassar:}

Ketua Sekolah Tinggi Theologia Jaffray Makassar, Pdt. Dr. Daniel Ronda, Th. M. mengemukakan bahwa:

"Sangat luar biasa perhatian warga masyarakat sekitar kampus STTJ Makassar, karena sudah puluhan tahun berdiri sekolah tersebut, keadaannya tetap aman dan selalu tercipta saling pengertian dan keharmonisan. Tentu sebagai orang yang taat pada agama masingmasing meyakini bahwa Allah mengizinkan dan menempatkan manusia-manusia yang berpengertian dan bersedia berdampingan sekalipun ada perbedaan keyakinan. Terjadinya saling pengertian dan harmonis tentu karena ditunjang oleh perilaku dan sikap pihak STTJ Makassar dalam hidup bertetangga dan mengutamakan kebersamaan dan toleransi serta kepedulian terhadap lingkungan, taat pada norma-norma yang pada masyarakat setempat." bahwa:

Pdt. Peniel C. D. Maiaweng, M. Th. (Puket III) bidang kemahasiswaan, mengatakan

"Hubungan antara warga kampus STTJ Makassar dengan masyarakat sekitarnya sangat baik dan harmonis, buktinya ketika mahasiswa dan dosen STTJ Makassar melakukan kerja bakti disekitar kampus, pasti warga ikut berperan seperti menyediakan air minum atau kue yang diberikan kepada orang yang sedang kerja bakti. Juga hubungan dengan pemerintah setempat kami menilainya bahwa sangat baik, karena samapai saat ini dari pihak pemerintah dalam hal ini, RT, RW dan keluarahan tidak ada yang menyampaikan keluhannya kepada pihak STTJ Makassar.

Hendrik Sello (42) adalah karyawan STTJ (putakawan) juga meyakini bahwa:

"Hubungan STTJ Makassar dengan masyarakat sekitarnya sangat akrab terbukti bahwa ketika terjadi kerusuhan di Makassar pada tahun 1998, justru masyarakat sekitar utamanya para tukang becak menjadi tameng disekitar kampus STTJ pada saat itu. Hal ini tentu masyarakat berupaya untuk melindungi STTJ dari segala ancaman karena kampus tersebut salah satu sumber mencari nafkah khususnya bagi tukang becak."

Yonathan Salong, M. Th. (35) Asisten Dosen merangkap sebagai staf Lembaga Penelitian dan Penerbitan STTJ Makassar berpendapat bahwa:

"Hubungan sosial antara warga kampus STTJ dan lingkungan sekitarnya itu sangat akrab. Salah satu contoh keakrapannya adalah, masyarakat disekitar kampus ikut memeriahkan beberapa kegiatan olah raga yang di adakan di kampus, seperti badminton, futsal dan beberapa yang lain. Pada acara-acara agamawi seperti Natal, Paskah, Puasa, dan Lebaran warga STTJ memberikan perhatian ekstra kepada masyarakat sekitar kususnya kepada 
mereka yang tidak mampu dalam hal pembagian sembako. Sebaliknya, keamanan dan perlindungan dari warga sekitar juga dirasakan oleh warga STTJ. Hubungan keakrapan ini adalah sebuah korelasi sosial antara warga STTJ dengan masyarakat sekitar yang harus tetap dipertahankan kalau perlu ditingkatkan.

\section{Mahasiswa STT Jaffray Makassar:}

Seorang mahasiswa S2 yang bernama Roy Kamasi, S.Th, dibesarkan disekitar kampus STTJ dan banyak bergaul dengan masyarakat sekitar, mengemukakan pendapat dan pengalamannya sebagai berikut:

"Pada jaman ia remaja di sekitar kampus STTJ sangat nampak hubungan antara masyarakat dengan dosen serta mahasiswa di STTJ Makassar, karena dosen aktif mengadakan perkunjungan dengan masyarakat sekitarnya, perkunjungan itu dilakukan bukan dengan maksud untuk mempengaruhi masyarakat yang non Kristen tetapi sebatas sebagai tetangga dan saat itu penduduk masing jarang sehingga berteman itu sangat dibutuhkan. Masyarakat menerima keberadaan STTJ Makassar karena nampak kepedulian yang dilakukan oleh dosen dan mahasiswa bila ada masyarakat yang mengalami kedukaan pasti masyarakat STTJ ada yang hadir dan memberi suatu rasa empati dan simpati sehingga masyarakat sekitar tetap menerima keberadaannya."

\section{Pembahasan}

Berdasarkan temuan temuan data sebelumnya, maka tahapan selanjutnya dalam Bab ini adalah melakukan analisis data dan dibahas dan didepenulisankan sehingga para pembaca dari karya ilmiah ini dapat memperoleh pengetahuan dan gambaran tentang topik ini.

Dalam suatu organisasi atau perusahaan yang berperan aktif melakukan sosialisasi atau penyampaian pesan ke khalayak adalah Public Relations, bahkan disuatu instansi pemerintah atau perusahaan Public Relations ini mempunyai peran yang sangat menentukan atau mampu menciptakan suatu citra dari perusahaan atau instansi tersebut baik milik pemerintah maupun swasta. Sekalipun di lembaga Sekolah Tinggi Theologia Jaffray Makassar, dalam strukturnya tidak ditemukan adanya satu bagian Public Relations secara melembaga, tetapi peran itu tetap ada dan sangat aktif melakukan tugas dan misinya.

Sebagaiamana Yang diungkapkan di muka bahwa sasaran untuk menjalin komunikasi yang dilakuan oleh pihak STTJ Makassar adalah anggota gereja yang tersebar di seluruh nusantara dan warga masyarakat secara khusus yang tinggal di sekitar kampus, untuk mencapainya maka ada langkah-langkah yang harus ditempuh yaitu strategi komunikasi.

\section{Strategi Komunikasi}

Strategi komunikasi meliputi perencanaan dan manajemen. Perencanaan strategi menyangkut tindakan apa yang akan dilakukan sedang manajemen meliputi hal itu terjadi.

Sesungguhnya suatu strategi adalah keseluruhan keputusan kondisional tentang tindakan yang akan dijalankan guna mencapai tujuan. Jadi merumuskan suatu strategi komunikasi berarti memperitungkan segala kondisi dan situasi (ruang dan waktu) yang dihadapi dan yang akan mungkin dihadapi di masa cepan, guna mencapai efektivitas. Jadi strategi komunikasi ini harus mampu menunjukkan bagaimana operasionalnya secara praktis dilakukan, dalam arti bahwa pendekatan (approach) bisa berbeda sewaktu-waktu tergantung pada situasi dan kondisi. Selain itu hal yang utama perlu diperhitungkan adalah mengenal khalayak atau sasaran. Kemudian berdasarkan pengalaman serta komunikator, yang dipilih sesuai situasi dan kondisi yang ada. Hal ini dimaksudkan agar kekuatan penangkal yang dimiliki oleh khalayak dapat dijinakkan juga untuk mengalahkan kekuatan pengaruh dari pesan-pesan lain dari sumber (komunikator) lain.

Berbicara tentang strategi komunikasi, berarti berbicara tentang bagaimana sebuah perubahan diciptakan pada kalayak dengan mudah dan cepat. Perubahan merupakan hasil proses komunikasi yang tidak mungkin dielakkan dan seharusnya tercapai. Bahkan melalui komunikasi dapat merubah sama sekali citra seseorang atau kelompok orang mengenai dirinya sendiri maupun lingkungannya. Itulah sebabnya komunikasi mempunyai kedudukan yang sangat strategis dalam keseluruhan perubahan masyarakat atau perubahan sosial.

Sejalan dengan pandangan tersebut di atas, oleh penulis melihat kesamaan pandangan dengan apa yang dilakukan oleh lembaga STT Jaffray Makassar dalam menjalin hubungan 
dengan masyarakat yaitu pendekatan yang dapat mempengaruhi hati dan jiwa baik secara individu maupun secara berkelompok dalam suatu lingkungan masyarakat.

Strategi komunikasi yang diterapkan oleh STT Jaffray Makassar dalam menampakkan citranya adalah sebagai berikut:

1. Dalam proses belajar mengajar di kelas sudah ditanamkan kepada mahasiswa tentang sikap dan perilaku sebagai seorang mahasiswa teologi yang harus tampil berbeda dengan disiplin ilmu lain, karena ilmu teologi adalah ilmu yang belajar tentang Tuhan yaitu sesuatu yang abstrak hanya dilihat oleh iman seseorang.

2. Dalam peraturan di lembaga STT Jaffray Makassar sudah diatur sedemikian rupa hal-hal yang harus menjadi kewajiban dan tanggung jawab seorang mahasiswa, dosen, karyawan dan keluarganya bahkan para alumni dimanapun berada nantinya.

3. Alumni STT Jaffray Makassar menjadi pembawa citra yang posotif kepada gereja-gereja dan masyarakat dimanapun mereka berada. Karena melalui perilaku yang ditampilkan oleh para alumninya akan memberi suatu pencitraan pada lembaga dimana mereka dibentuk atau dididik sebelumnya, sehingga penulis berkesimpulan bahwa alumni sangat berperan besar untuk pencitraan STT Jaffray Makassar untuk gereja-gerja yang tersebar di nusantara ini.

4. Demikian juga dalam membangun hubungan yang harmonis dengan masyarakat sekitarnya, tetap menjadi prioritas utama adalah dimulai dari lingkungan kampus itu sendiri yaitu dosen, mahasiswa dan karyawan serta keluarganya harus tampil dengan penuh kekeluargaan yang tidak bertentangan dengan norma-norma yang ada dalam masyarakat setempat, misalnya bersilahturahmi dengan masyarakat, bergaul dengan tidak menampilkan gaya yang membuat orang lain tersinggung, memiliki prilaku yang penuh perhatian yang penuh ketulusan, menciptakan suatu kerja sama yang baik untuk mencapai kebersamaan, kebagagiaan dan keamanan.

Dengan bercermin pada beberapa kampus perguruan tinggi baik di Makassar maupun di tempat lain, sering terjadi bentrok atau konflik antara mahasiswa dengan masyarakat sekitarnya, atau mahasiswa perguruan tinggi lain yang datang menyerang. Juga sering terjadi konflik antara pimpinan dan mahasiswa dan karyawannya. Peritiwa konflik yang terjadi seperti di atas adalah disebabkan karena fungsi Public Relations tidak maksimal secara khusus pembinaan secara internal organisasi atau kampus tersebut.

Hal lain yang perna terjadi di STT Doulos Cipaying- Jakarta, dimana sekolah tersebut ditutup oleh warga Cipayung, karena dari awal sudah tidak ada persetujuan dari kamunitas setempat, tetapi pihak Doulos tetap berupaya dengan segala cara dengan istilah pada saat itu " turun gunung" terhadap warga untuk mengungkapkan keuntungan buat warga sekitar tetapi hasilnya adalah nihil justru terjadi bentrok dan lokasi tersebut tidak dapat dimanfaatkan lagi kecuali kalau pihak Doulos menjualnya kepada pihak ketiga.

\section{Faktor Mempengaruhi Strategi Komunikasi}

Dalam membangun strategi komunikasi ada faktor-faktor yang dapat mempengaruhi sehingga berhasil atau tidaknya suatu komunikasi yaitu:

1 Kemampuan seorang komunikator untuk menyampaikan pesan kepada komunikan sehingga tujuan itu dapat tercapai dan dipahami dengan baik.

2 Isi pesan yang disampaikan oleh komunikator tidak bersesuaian dengan kebutuhan komunikan atau isi pesannya tidak jelas., mungkin bertele-tele.

3 Komunikan tidak tertarik pada isi pesan dari komunikator karena mengandung hanya kepentingan sepihak belaka.

4 Sarana penyampaian suatu pesan kepada komunikan juga dapat mempengaruhi.

5 Komunikator dan komunikan apakah ada persesuaian dalam hal suatu pandangan.

6 Kebudayaan, agama, pendidikan dan status sosial. Hal ini juga sangat mempengaruhi suatu keberhasilan dalam berkomunikasi. Sering terjadi karena tidak sekeyakinan atau budaya yang berbeda status sosialnya juga berbeda maka proses komunikasinya dapat terhambat.

7 Faktor lingkungan sosial dan kondisi fisik, misalnya di suatu daerah lingkungan sosial masyarakatnya cenderung tidak menerima pendapat dari luar maka hal itu mempengaruhi hasil, demikian juga faktor fisik, misalnya orangnya tuli. 


\section{Kesimpulan}

\section{PENUTUP}

Setelah penulis mengadakan penelitian secara seksama kemudian memberikan uraian serta tanggapan dari hasil yang didapatkan di lapangan maka melalui bab V ini penulis akan memberikan kesimpulan yang menjadi pendapat akhir yang sangat diharapkan sebagai masukan yang berharga dikemudian hari bagi institusi/ lembaga juga kepada siapa saja yang membaca karya ilmiah ini.

Berdasarkan dengan rumusan masalah, upaya apa yang dilakukan oleh Lembaga Sekolah Tinggi Theologia Jaffray Makassar terhadap masyarakat sekitarnya?, dan apakah masyarakat merasakan ada kepedulian dari Civitas Akademika \& Tenanaga kependidikan Sekolah Tinggi Theologia Jaffray Makassar ?. Setelah mengumpulkan data dari berbagai sumber yaitu dari masyarakat sekitarnya dan kalangan dosen, mahasiswa dan karyawan STT Jaffray Makassar penulis memberi kesimpulan sebagai berikut:

Pada dasarnya keberadaan Sekolah Tinggi Theologia Jaffray Makassar mendapat dukungan dari masyarakat sekitar karena keberadaannya tidak mengganggu aktivitas warga atau masyarakat, justru menjadi salah satu tempat untuk mendapatkan rejeki bagi sebagian penduduk, misalnya yang ada usaha toko, karena mahasiswa dan dosen pasti membeli segala kebutuhannya di toko terdekat. Penduduk yang memiliki usaha Rumah Kontrakan (kost) juga merasa tertolong karena setiap saat rumah kontrakannya akan laku dan selalu berpenghuni.

Kegiatan Sosial, Ternyata oleh masyarakat sekitar kampus STTJ Makassar merasakan manfaat kehadiran sekolah tersebut karena mahasiswa dan dosennya sering mengadakan bersih-bersih lingkungan, sehingga selokan dan jalan-jalan mereka menjadi bersih. Kegiatan Keagamaan, Sekalipun STTJ Makassar adalah komunitas Kristen karena sekolah tersebut adalah tempat pembinaan dan pembentukan pemimpin-pemimpin Kristen, tetapi ada rasa toleransi yang dilakukan terhadap masyarakat yang ada disekitarnya khususnya yang beragama islam, kepada mereka diberikan kesempatan untuk melaksanakan acara buka bersama tanpa berlatarbelakang lain tetapi murni adalah mau menyatakan niat yang tulus terhadap sesama khususnya umat islam yang lagi berpuasa. STTJ Makassar juga sering kerja sama dengan warga setempat dan pemerintah untuk menyiapkan binatang kurban seperti kambing, sehingga masyarakat yang berhak untuk itu dapat menikmatinya.

Sekolah Tinggi Theologia Jaffray Makassar dalam menciptakan strategi komunikasi dapat memanfaatkan semua komponen yang ada yaitu dosen, karyawan dan mahasiswa bahkan alumni dalam menampilkan pencitraan positif lembaga tersebut melalui perilaku dan tindakan setiap komponen tersebut di atas. Perlu dipahami juga bahwa dalam struktur STTJ Makassar tidak ditemukannya bagian Public Relations (Humas) tetapi untuk fungsi tersebut sudah melekat dalam diri pribadi dosen, mahasiswa dan karyawan untuk hal pencitraan.

Sekolah Tinggi Theologia Jaffray Makassar dalam membangun hubungan yang harmonis dengan masyarakat di sekitarnya ternyata mendapat dukungan dari berbagai pihak, utamanya warga setempat dan pemerintah, sesuai pengakuan dari beberapa orang yang menjadi koresponden penulis dalam mengumpulkan data selama penelitian ini berlangsung. Tentu pengakuan ini berdasarkan fakta yang ada di lapangan.

Bukti lain adalah STT Jaffray Makassar sudah berdiri sejak tahun 1932 hingga sekarang di tempat tersebut, dalam catatan sejarahnya tidak perna terjadi konflik antara warga atau dengan kelompok lain.

Berdasarkan berbagai pengalaman dan bukti-bukti yang terjadi di lapangan bahwa suatu aktivitas yang dilakukan tanpa persetujuan dengan komunitas atau warga sekitar maka hal itu memungkinkan terjadi hubungan yang disharmonis alias konflik.

\section{Saran-Saran}

Untuk meningkatkan hubungan yang harmonis dengan masyarakat sekitar kampus STTJ Makassar maka yang perlu dilakukan adalah:

1 Membuka diri yaitu meningkatkan hubungan secara personal dengan warga yang berada di sekitar kampus STTJ Makassar, melalui silaturahmi setiap saat, terlebih pada hari raya keagamaan, baik hari raya muslim maupun non muslim.

2 Melakukan bakti sosial bersama masyarakat sekitar dan warga kampus, misalnya program sabtu bersih yang dapat dilakuan satu kali dalam sebulan. 
3 Meningkatkan komunikasi dengan pihak pemerintah, dalam hal ini mulai dari RT, RW, dan keluarahan.

4 Mendukung kegiatan-kegiatan yang dilakukan oleh warga sekitar misalnya perayaan HUT Kemerdekaan RI yang selalu dilakukan setiap tahun.

5 Pihak STT Jaffray Makassar dapat mengadakan pelayanan sosial secara gratis kepada warga, misalnya pengobatan, dan sunatan.

6 Mengadakan seminar atau ceramah keagamaan yang bernuansa lintas agama dari semua agama.

7 Sebaiknya dalam Struktur STTJ Makassar nampak adanya satu bagian Humas atau PR.

\section{DAFTAR PUSTAKA}

\section{Sumber dari buku teks ( textbook )}

Abdulsyani. 2004. Sosiologi Skematika, Teori, Dan Terapan. Jakarta : Bimi Aksara.

Arifin, H. Anwar. 1995. Ilmu Komunkasi: Sebuah Pengantar Ringkas. Jakarta: Grafindo Persada.

Bungin, H.M. Burhan. 2007. Sosiologi Komunikasi: Teori, paradigma, dan diskursus teknologi komunikasi di masyarakat. Jakarta: Kencana.

Cangara, H. Hafied.2008. Pengantar Ilmu Komunikasi. Jakarta: PT. Raja Grafindo Persada.

Effendy, Onong Uchana. 1998. Human Relations Dan Public Relations. Bandung : Mandar Maju.

Fisher, B. Aubrey. 1986. Teori-Teori Komunikasi: Perspektif Mekanistis, Psikologis, Interpersonal, dan Pragmatis. Bandung: Remaja Karya.

Hardjana, Agus M. 2003. Komunikasi Intrapersonal Dan Interpersonal. Yogyakarta: Kanisius.

Heylin, Angela. 2002. Kiat Sukses Komunikasi: Langkah-langkah Praktis Untuk Berhasil. Jakarta: Mitra Utama.

Iriantara, Yosal. 2004. Community Relations: Konsep Dan Aplikasinya. Bandung: Simbiiosa Rekatama Media.

Kincaid, D. Lawrence \& Wilbur Schramm. 1981. Asas-asas Komunikasi Antar Manusia. Jakarta: LP3ES.

Muliana, Deddy. 2005. Ilmu Komunikasi: Suatu Pengantar. Bandung: PT. Remaja Rosdakarya.

Muliana, Deddy. 2005. Komunikasi Efektif: Suatu pendekatan lintas budaya. Bandung: PT. Remaja Rosdakarya.

Mursalim. 2007. Dasar-Dasar Penelitian Komunikasi. Makassar: STIKOM Fajar Makassar.

Nurdin,. 2008. Sistem Komunikasi Indonesia. Jakarta: PT. Raja Gratindo Persada.

Rumanti, St. Maria Assumpta. 2004. Dasar-Dasar Public Relations: Teori dan Praktek. Jakarta: PT. Gramedia Widiasarana Indonesia.

Rumondor, Alex H. 1995. Komunikasi Antar Budaya: Materi Pokok

Ruslan, Rosadi. 2005. Manajemen Public Relations e Media Komunikasi: Konsepsi dan Aplikasi,. Jakarta: PT. Raja Grafindo Persada.

Sendjaja, Sasa Djuarsa. 1993. Pengantar Komunikasi: Materi Pokok Ikom 4130/3sks/modul 1-9. Jakarta: Universitas Terbuka.

Siahaan, S.M. 1991. Komunikasi: Pemahaman dan penerapannya. Jakarta: Gunung Mulia.

Singarimbun, Masri \& Sofian Efendi ( Editor ) 2006. Metode Penelitian Survei. Jakarta: LP3S.

Susanto, Astrid S. 1977. Pengantar Sosiologi Dan Perubahan Sosial. Bandung: Binacipta.

Tondowidjojo, John. 2004. Dasar Dan Arah Public Relations.Jakarta: Gramedia.

Sumber dari Kamus

Tim Penyusun Kamus Pusat bahasa. 2005. Kamus Besar Bahasa Indonesia. Jakarta: Balai Pustaka .

Reading, Hugo F. 1986. Kamus Ilmu-Ilmu Sosial. Jakarta: CV. Rajawali.

Prent, K. dkk. 1969. Kamus Latin - Indonesia. Semarang: Kanisius.

Sumber dari internet

Bugi, Muhammad. 2007. Empat Kunci Rumah Tangga Harmonis. (http://www.dakwatuna.com/2007/4-kunci-rumah-tangga-harmonis. diakses 06 April 2010 pukul 13.42 WITA ).

Damayanti, Nindya. 2010. Interkasi Harmonis Antara Teknologi Modern Dan Budaya Tradisi Indonesia. (http://www.mail-archive.com/artculture-indonesia@yahoogroups.co. diakses pada tanggal 06 April 2010 pukul 13.51. WITA) 